Ankara Ecz. Fak. Mec.

7. 141 (1977)
J. Fac, Pharm Ankara

7. 141 (1977)

\title{
Nişasta Kalitesinin Askorbik Asit Tabletlerinin Stabilitesi Üzerine Etkileri
}

The Effects Of the Starch Quality on the Stability of Ascorbic Acid Tablets*

Çalışmanın amacı Ülkemizde elde edilen değişik küçük sanayi ve büyük sanayi nişastaları ile hazırlanmış Askorbik Asid tabletlerinde Nişasta türlerinin etken maddenin dayanıklılığı üzerindeki etkilerini incelemektedir. İncelenen tabletlerde etken madde olarak Kristal ve Kaplanmış Askorbik Asid kullanılmıştır. Nişasta olarak a) Ưlkemizde halkımızın evde veya ev koşullarında elde edilen küçük sanayi tipi nişastalarla, b) Ülkemizde endüstriel metodlarla elde edilen büyük sanayi tipi nişastalar kullanılmıştır.

Birçok maddelerin Askorbik Asid tabletlerinin stabilitesindeki etkileri (1) evvelce belirtilmiş olduğundan biz özellikle nişasta türlerinin etkilerini incelemek için bütün tablet formüllerinde aynı kaydırıcı ve yapışmayı önleyici maddeleri kullandık. Deneyleri dört değişik bağıl rutubet ve üç değişik temperatür ortamında yürüttük.

Askorbik Asid tabletlerinde değişik bağıl nem ve değişik temperatürde oluşan kimyasal parçalanma bir, iki ve üç aylık sürelerde kimyasal tayinlerle saptandi. Askorbik Asid tabletleri ayrıca fiziksel yönden de incelenerek tabletlerin renklenme oranı, dağılma zamanları ve sertlikleri yönünden de sonuçlar değerlendirildi. Bu deney-

Redaksiyona verildiği tarih: 1 Aralık 1977

* Ecz. Necati Dikmen'in aym isimli doktora tezinin özetidir. Sinav Tarihi : Kasim 1976.

** Farmastötik Teknoloji Kürsüsü, Eczacıllk Fakültesi, Ankara Üniversitesi

*** Gülhane Askerî Tıp Akademisi Ankara, Türkiye. 
lerden sonra Askorbik Asid tabletlerinde bağlayıcı ve seyreltici olarak kullanılan çeşitli nişastalar Protein içerikleri yönünden ve Madensel maddeler yönünden de incelendi.

$\mathrm{Bu}$ incelemelerde nişasta türlerinin kalitesi yanında Askorbik Asid tabletlerinin stabilitesinde zaman, rutubet, temperatür faktörlerinin etkiside araştırılmıştır.

Tablet formüllerinde bağlayıcı ve seyreltici olarak mikrokristal sellüloz ve çözünebilen misır nişastası (STR-x-1500)'da kullanılmıştır. Bu iki dolgu maddesinin kullanılmasındaki maksat Endürtri Nişastası ile Ev Nişastalarının, Askorbik Asid Stabilitesine etkisinin ortaya çıkarılmasında mukayeseli çalı̧ma yapmaktır.

Askorbik Asidin gerek çözelti gerekse tablet şeklindeki preparatlarındaki stabilitesi üzerine literatürde geniş çalışmalar mevcut isede $(2,3,4)$ Endüstriel ve Evde imâl edilmiş nişasta çeşitleri ile hazırlanan Askorbik Asid Tabletlerinin stabilitesi üzerinde bir çalı̧maya rastlanmamiştır.

Özetle amacımız ƯIkemizde elde edilen değişik ev ve Endüstri nişastaları ile hazırlanmış Askorbik Asid tabletlerinde etken maddeyi en dayanıkl halde tutacak nişasta cinsini saptamak ve Farmasötik teknolojiye bilimsel bir katkıda bulunmaktır.

\section{MATERYAL VE YÖNTEM}

A-Kimyasal Maddeler: Buğday Nişastası (Endüstri tipi Vaniköy, İstanbul), (Endüstri tipi, Nişko, Adapazarı), Patates Nişastası (Endüstri tipi, Çapı Marka İstanbul), Buğday Nişastası (Ev, tipi küçük imalât, Tokat, Reşadiye, Kuzbağı Köyü) Mısır Nişastası (Ev, tipi küçük imalât, Samsun, Çarşamba), Patates Nişastası (Ev tipi küçük imalât, Erzurum, Hasankale), Mağnezyum Stearat, Talk, Aerozil, Mikrokristal Selluloz, Eriyebilen Misır Nişastası (Farmasötik Kalitede)

Askorbik Asid Kristal toz (E. Merck, Darmstad), Kaplanmış Askorbik Asid (Mikrokapsül, Roche).

1-(+) Askorbik Asid ve d (t) Askorbik Asid olmak üzere iki şekli vardır. $1(+)$ Askorbik Asid biolojik aktiftir, oksitlenmekle iki hidrojen atomu kaybeder ve dehidro-1-Askorbik Asid meydana gelir, bu reaksion geri dönüssebilir. Gerek-1- Askorbik Asid ve gerekse 
dehidro -1- Askorbik Asidin her ikiside biolojik aktiftirler. Dehidro -1- Askorbik Asidde bir molekül su alarak 2,3 diketo -1- gulonik aside dönüşür. Bu reaksion geri dönmez olduğu gibi husule gelen bileşiğinde biolojik aktivitesi yoktur. Bu hidratasyon nötral veya alkali çözeltilerde kendiliğinden husule gelir. 2,3 diketo -1- gulonik asidde çok dayaniksız olduğundan oksalik asid ve 1- treonik aside parçalanır. $(5,6)$ Askorbik Asidin oksitlenerek parçalanmasını bazı metaller özellikle bakır ve demir hızlandırır. $(7,8,9)$.

Nişastalar: Buğday ve patates nişastalarının çözeltileri çoğunlukla hafif asid, pirinç nişastası çözeltisi hafifçe alkali ve misır nişastası çözeltisi nötrdür.

Buğday, misır ve pirinçten elde edilen ve havada kurutulmuş nişasta \% 13 civarında ortalama nem içerir. Nişastalar \% 35 ilâ 37 ye kadar nem çekebilir. (10).

Hububatlardan elde edilen nişasta granüllerinin çapları $3-30 \mu$ arasında değişik, kök ve yumrulardan elde edilen nişastaların çapları 10-100 $\mu$ arasındadır. (10) Nişastanın takribi formülü $\left(\mathrm{C}_{6} \mathrm{H}_{10} \mathrm{O}_{5}\right) \mathrm{n}$ dir, n, birkaç yüz ilâ bir milyon olabilir. (11)

Nişastanın kimyasal olarak sentezi yapılamamıştır. (12)

Ev (küçük imalât) Nişastalarının elde edilişi;

a- Patates Nişastası, (Erzurum ili yöntemi):

Patates yumruları su ile yıkanarak temizlenir, temiz yumrular uygun bir rende ile rendelenir veya kiyma makinasinda yumrular kıyılır, üzerine su ilâve edilir. Patates kabukları suyun yüzünden alımır, nişastanın dibe çökmesi için beklenir. Ustte kalan su tabakası aktarılır, tekrar taze su konur, karıştırılır, tekrar nişasta çökmeğe bırakılır. Su tabakası aktarılır, su ile yıkama işlemi 5-6 defa tekrar edilir, Nişasta kütlesi kurutulmaya bırakılır.

\section{$b_{1}$ - Misır Nişastası (Samsun Lâdik İlçesi Yöntemi)}

Misır taneleri llik suda $40^{\circ} \mathrm{C}$ de kokuşuncaya kadar tutulur, kokuşan misır suyu ile beraber ezilir ve tel bir elekten geçirilir, elekten geçen kısımlar su ile beraber bir kaç gün bekletildikten sonra, nişasta kabın dibine çöker, üstte kalan sulu tabaka aktarılarak atılır, Nişasta ince tabakalar halinde tepsilere yayllır, güneşte veya hafif 
ateşli firında kurutulur, toz edilir, eleklerden elenir. Alta geçen kısım hakiki nişastadır.

$b_{2}-$ Mısır Nişastası (Antalya, Serik İlçesi Boztepe Köyü Yöntemi)

Misır taneleri bezden bir çuvala konur, çuval bağlı olarak bir dere kenarına tesbit edilerek, çuval dereye daldırılır, Ģuval dere içerisinde iken bir süre sonra çuvaldan fena kokular yayılır, 5 ilâ 10 gün sonra fena kokular kaybolur nişasta kokusu meydana gelir, o zaman çuval dereden alınır, çuvalın içeriği bir kaba boşaltılır hamur haline kadar ezilir, su ile karıtştırılır, sulu tabaka başka bir kaba ahınır, hamur üzerine tekrar su ilâve edilir, tekrar sular alınır, geriye kalan posa bezden torbalarda sıkılarak sular alınır. Posa atılır, sulu tabakadaki nişasta çökmeğe terk edilir, üstte kalan sular aktarılarak atılır, dipteki nişasta tabakası kurutulur, toz edilir.

\section{$b_{3}-$ Misır Nişastası (Samsun, Çarşamba İlçesi Yöntemi)}

Mısır taneleri yıkanarak geniş ağızlı kaplara konur, üzerine su ilâve edilir, mısır taneleri parmak arasında sıkıldığında süt gibi bir kısım çıkıncaya kadar bekletilir. Bu süre 15-20 gündür, süre sonunda taneler içerisinde su bulunan bir kaba dökülür ve ezilir. Hamur haline gelen nişasta su ile sulandırılır, kütle el ile sıkılarak posa nişasta sütünden ayırt edilir. Nişasta sütü torbaya konur, süzülmesi beklenir. Hamur halindeki nişasta bezler üzerine serilerek güneşte kurutulur. Bir hafta içerisinde kütle ince bir elekten elenir, eleğin altına geçen kısım hakiki nişastadır.

c- Buğday Nişastası (Tokat, Reşadiye Kuzbağı Köyü Yöntemi)

Buğday taneleri yıkanarak temizlenir, tahta bir küvete konur, üzerine bol miktarda su ilâve edilir, bu su iki üç günde bir defa değiştirilir, bu işleme 10-15 gün devam edilir. Buğday yoğurt kıvamına gelince tekrar su ile karıştırılır ve elde ovularak ezilir.

Karışım çökmeğe birakılır, eğer varsa kabuk, yabancı maddeler su akımı ile atılır, tekrar su ilâve edilerek karışım ovulur, karıştırılır, tekrar çökmeğe terk edilir, sulu tabaka aktarılır, dibe çöken sulu bulamaç içerisine, kuru kireç içeren bez bir torba daldırılır, kuru kireç karışımın suyunu alır, suyu alınmış karışım tepsilere dökülür, kurutulur, ezilir ve ince madenî eleklerin alt tarafina geçen kısım buğday nişastasıdır, bu nişasta özellikle sert buğdaydan yapılır. 
B- Alet ve Cihazlar: Çift kapılı etüv, Desikatör Cam, Elek makinası Erweka, Etüv tek kapılı Ehret, Granülatör Erweka, Kjeldahl külleme üniti, Kjeldahl cihazı yarı mikro, Manyetik karıştırıcı L.P., Mikroskop A.O. Spancer, Tablet dağılma test cihazı Manesty, tablet sertlik tayin cihazı Monsanto, tabket makinası korsh, toz karıştırıcı Erweka, Vakum cihazı Kurz Drückew, Vakumlu etüv Heraeus R.Ü.T., Cam kapaklı kauçuk Rondelalı kavanozlar.

C- Bağıl Rutuber Ortamları: $40^{\circ} \mathrm{C} \% 75$ R.H., $20^{\circ} \mathrm{C} \% 75$ R.H., $24^{\circ} \mathrm{C} \% 51$ R.H., $20^{\circ} \mathrm{C} \% 20$ R.H.

Ưlkemizde Endüstride ve evde elde edilen çeşitli nişasta türleri ile yapılan tabletlerin sıcaklık ve Bağıl nemde değişik yöntemleri ile stabilitesini incelemek için, ülkemizin çeşitli bölgelerinin yıllık ortalama bağıl rutubetini araştırdık. Devlet Meteoroloji Enstitüsünden alınan 1974 yılına ait değerlerden esinlenerek bağıl rutubet vasatları tanzim edildi.

Ülkemizin en az bağıl nem ortalaması \% 51 ile en fazla bağıl nem ortalaması $\% 74$ arasında değişmektedir.

\section{YÖNTEM}

I- Askorbik Asid Tabletlerinin yaş yöntemle (13) hazırlanmasindaki özellikler:

a) Tabletlerin bir kısmı kristal toz Askorbik Asid ile diğer kısmı kaplanmış Askorbik Asid ile hazırlandı. kullanıldı.

b) Bütün tabletlerde bağlayıcı olarak nişasta müsilâjı ( $\%$ 10)

c) Seyreltici olarak nişasta ve laktoz, yapışmayı önleyici olarak talk ve kolloidal silika (Aerozil), Sürtünmeyi önleyici olarak mağnezyum stearat, Dağılmayı sağlayıcı olarak nişasta kullanıldı.

Her formülde kullanılan seyreltici, dağıtıcı ve bağlayıcı olarak aynı cins nişastalar alınmıştır. Tabletlerde kullanılan nişastalar No: 85 elekten elenip $105^{\circ} \mathrm{C}^{\prime}$ de etüvde 2 saat kurutulduktan sonra kullanulmıştır.

Her tablet $300 \mathrm{mg}$. Askorbik Asid içermektedir, tabletin sıvağlı ağırhı̆ı $500 \mathrm{mg}$. dir. 
Tabletler yaş yöntemin genel kuralları (13) içerisinde Korsh tek zımbalı tablet makinasında, 1,5 ton $\mathrm{cm}^{2}$ basınçla $12 \mathrm{~mm}$. çapinda, düz yüzeyli zımbalarla hazırlandı.

II. Kuru Granül Yapma Yöntemi ile Askorbik Asid Hazırlanması :

Askorbik Asid tabletleri Mikrokristal sellüloz ve çözünebilen mısır nişastası STR-x-1500 yardımıyla ve yapışmayı önleyici olarak talk ve Aerozil, sürtünmeyi önleyici olarak Mağnezyum Stearat kullanarak hazırlandı. (13, 14) Tabletler yaş yöntemde olduğu gibi 12 mm. çapında 1,5 ton $\mathrm{cm}^{2}$ basınçla hazırlandı. Kuru yöntemle hazırlanan tabletler $500 \mathrm{mg}$. olup $300 \mathrm{mg}$. etken madde taşır.

III. Askorbik Asid Tabletlerinde, Askorbik Asid Miktar Tayini: 2,6 diklorfenol yöntemi (15) ile 20 şer tablet kullanarak yapıldı.

IV. Nişastalarda (ev tipi, küçük imalât ve endüstri tipi) Azot (PROTEIN) tayini:

Yarı mikro Kjeldahl cihazı ile yapıldı. (16)

V. Nişastalarda (ev tipi küçük imalât ve Endüstri Tipi) Kül Tayini: Kuru külleme yöntemi ile yapıldı. (9)

VI. Nişastalarda (ev tipi küçük imalât ve Endüstri Tipi) Bakır Tayini: Biazzopyridine-thiocyanat kolorimetrik yöntemi ile yapıldı. (17-18).

\section{BULGULAR}

Askorbik Asid tabletlerinde kullanılan Talk ve Mağnezyum Stearatın literatürde renklenmeyi hızlandırıcı etkisi belirtilmiştir. (1) Biz özellikle renklenme üzerine nişasta türlerinin etkilerini incelemekamacını güttüğümüzden Talk ve Mağnezyum Stearatı her formülde sabit bir miktarda kullandık.

Formüllerde değişen tek faktör, etkisini incelediğimiz seyreltici ve bağlayıcı olan nişasta türleridir. Bu suretle seyreltici ve bağlayıcıların Askorbik Asid tabletlerinin stabilitesine ne oranda hızlandırıcı ve ne oranda önleyici etkisinin olduğunu incelemeye çalıştık. Askorbik Asid tabletlerinde seyreltici ve bağlayıcıların (nişasta türlerinin) stabilite yönünden etkisini incelemek maksadile ondört ayrı tablet formülü hazırladık, bunların yedisi kristal Askorbik Asid ile (Tablo -I), diğer yedisi kaplanmış Askorbik Asidle hazırlandı (Tablo-II). 
Tablo I. Yüzde ağırlığa Göre Kristal Askorbik Asidle Hazırlanan Tablet Formülleri

\begin{tabular}{|l|c|c|c|c|c|c|c|}
\hline Formüller & 1 & 2 & 3 & 4 & 5 & 6 & 7 \\
\hline Askorbik Asid Kristal Toz & 60 & 60 & 60 & 60 & 60 & 60 & 60 \\
Buğday Nişastası (Endüstri) & 20 & - & - & - & - & - & - \\
Misır Nişastası (Endüstri) & - & 20 & - & - & - & - & - \\
Patates Nişastası (Endüstri) & - & - & 20 & - & - & - & - \\
Buğday Nişastası Ev Tipi & - & - & - & 20 & - & - & - \\
Patates Nişastası Ev Tipi & - & - & - & - & 20 & - & - \\
Eriyebilen Nişasta (STR-x-1500) & - & - & - & - & - & 20 & - \\
Mikrokristalin Sellüloz & - & - & - & - & - & - & 20 \\
Laktoz & 16 & 16 & 16 & 16 & 16 & 16 & 16 \\
Talk & 2.5 & 2.5 & 2.5 & 2.5 & 2.5 & 2.5 & 2.5 \\
Mağnezyum Stearat & 1 & 1 & 1 & 1 & 1 & 1 & 1 \\
Aerozil & 0.5 & 0.5 & 0.5 & 0.5 & 0.5 & 0.5 & 0.5 \\
\hline
\end{tabular}

Tablo II. Yüzde Ağırlığa Göre Kaplanmış Askorbik Asid ile Hazırlanan Tablet Formülleri

\begin{tabular}{|l|c|c|c|c|c|c|c|}
\hline Formüller & 8 & 9 & 10 & 11 & 12 & 13 & 14 \\
\hline Kaplanmis Askorbik Asid & 60 & 60 & 60 & 60 & 60 & 60 & 60 \\
Buğday Nişastası (Endüstri) & 20 & - & - & - & - & - & - \\
Misır Nișastası (Endüstri) & - & 20 & - & - & - & - & - \\
Patates Nişastası (Endüstri) & - & - & 20 & - & - & - & - \\
Buğday Nişastası Ev Tipi & - & - & - & 20 & - & - & - \\
Patates Nişastası Ev Tipi & - & - & - & - & 20 & - & - \\
Eriyebilen Nissasta (STR-x-1500) & - & - & - & - & - & 20 & - \\
Mikrokristalin Selüloz & - & - & - & - & - & - & 20 \\
Laktoz & 16 & 16 & 16 & 16 & 16 & 16 & 16 \\
Talk & 2.5 & 2.5 & 2.5 & 2.5 & 2.5 & 2.5 & 2.5 \\
Mağnezyum Stearat & 1 & 1 & 1 & 1 & 1 & 1 & 1 \\
Aerozil & 0.5 & 0.5 & 0.5 & 0.5 & 0.5 & 0.5 & 0.5 \\
\hline
\end{tabular}

Ondört tablet formülünden (Tablo-I, II) 6, 7, 13, 14 nolu formüller kuru yöntemle $1,2,3,4,5,8,9,10,11,12$ nolu tablet formülleri, yaş yöntemle, nişasta müsilâjı ile hazırlanmışlardır.

Tabletler bal renkli, vidalı kapaklı cam kavanozlarda muhafaza edildi. Tabletler imâl edilir edilmez, Askorbik Asid miktar tayini yapıldı (15) ve sonra çabuklaştırılmış stabilite testlerine tabi tutuldu. Stabilite testleri dört ayrı bağıl nem (R.H.) ve üç ayrı sıcaklık derecesinde dört grup halinde yapıldı. Bağıl nemler (Tablo-III) doymuş tuz çözeltileri yardımı ile sağlandı. $(19,1)$ Ondört ayrı Askorbik Asid formülü, dört ayrı nem ve üç ayrı sıcaklıkta, birer aylık periyotlar halinde üç ay süre ile teste tabi tutuldu. Tabletler stabilite testlerine tabi tutulmadan 
Tablo III. Bağıl nem ve Sıcaklık dereceleri

\begin{tabular}{|c|c|}
\hline Sıcaklık Derecesi & Bağıl Nem (\% R.H.) \\
\hline $40^{\circ} \mathrm{C}$ & 75 \\
$24^{\circ} \mathrm{C}$ & 51 \\
$20^{\circ} \mathrm{C}$ & 75 \\
$20^{\circ} \mathrm{C}$ & 20 \\
\hline
\end{tabular}

a) Tabletlerde etken madde miktar tayini.

b) Fizik kontroller

c) Tablet sertlik kontrolü

d) Tablet dağılma kontrolleri

yapildı.

Bundan sonra tabletler belirtilen şartlarda önce bir ay tutuldu bu süre sonunda gruplardaki değişiklikler saptandı. Saptadığımız bulgulara göre dördüncü grupta $20^{\circ} \mathrm{C}$ de- \% 20 R.H.'da bir aylık süre içerisinde hiç bir değişiklik olmadı. Yani tabletler ilk imâl edildikleri andaki durumlarını aynen koruduğu için bu grup stabilite testlerinden çıkarıldı. Bundan sonra testlere üç grup üzerinde de devamla, her grubun durumu her ay sonunda ayrı ayrı tesbit edildi.

Buna göre $40^{\circ} \mathrm{C}$ de \% 75 R.H.'da stabilite testlerine tabi tutulmuş Askorbik Asid tabletlerinin etken madde kaybı yüzde olarak ve yüzde ortalama etken madde kaybı Tablo-IV'de görülmektedir.

Tablo IV. ( $40^{\circ} \mathrm{C}, \% 75$ R.H.)

\begin{tabular}{|c|c|c|c|c|}
\hline Formül & $\begin{array}{l}\text { Başlangıç } \\
\% \text { Aktivite }\end{array}$ & $\begin{array}{l}\text { 1. Ay \% } \\
\text { Kaypp }\end{array}$ & $\begin{array}{l}\text { 2. Ay \% } \\
\text { Kayıp }\end{array}$ & $\begin{array}{r}\text { 3. Ay\% } \\
\text { Kayıp }\end{array}$ \\
\hline $\begin{array}{r}1 \\
2 \\
3 \\
4 \\
5 \\
6 \\
7 \\
8 \\
9 \\
10 \\
11 \\
12 \\
13 \\
14\end{array}$ & $\begin{array}{l}100 \\
100 \\
99,6 \\
99,3 \\
102,5 \\
101 \\
102,5 \\
103 \\
108,5 \\
101 \\
100,5 \\
106 \\
100,4 \\
101\end{array}$ & $\begin{array}{l}2 \\
1,5 \\
1,6 \\
6,85 \\
7,4 \\
5,3 \\
2,5 \\
3 \\
4,3 \\
5,2 \\
6,8 \\
6 \\
4 \\
2,8\end{array}$ & $\begin{array}{l}8,1 \\
5,26 \\
3,2 \\
6,85 \\
8,4 \\
7,6 \\
5,1 \\
4 \\
4,8 \\
5,2 \\
8 \\
9,2 \\
4,6 \\
3\end{array}$ & $\begin{array}{c}8,1 \\
5,26 \\
4,28 \\
12,9 \\
9 \\
7,9 \\
7,3 \\
4,5 \\
5,8 \\
8 \\
13,5 \\
11,5 \\
5,1 \\
4,1\end{array}$ \\
\hline \multicolumn{2}{|c|}{ Ortalama \% Kayıp } & 4,2 & 5,9 & 7,5 \\
\hline
\end{tabular}


Tablo-IV'deki değerler incelenerek stabilite testlerinde etken maddenin en çok kayba uğradığı, dört formül ile etken maddenin en az kayba uğradığı dört formül, zamana karşı \% etken madde kaybı grafiğinde gösterilirse (Grafik-I) burada ondört ayrı formülde etken madde kaybı (stabilite) yönünden 11, 4, 12, 5 nolu formüller en büyük değer kaybına uğramıştır. Buna mukabil 13, 8, 3, 14 nolu formüller en az değer kaybına uğramışlardır.

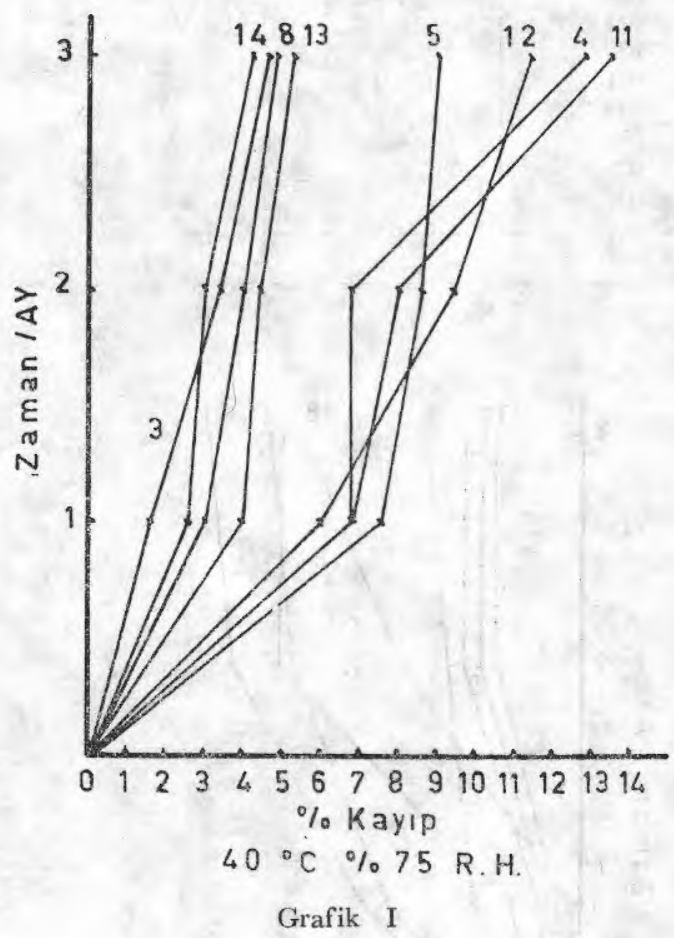

$24^{\circ} \mathrm{C}$ de \% 51 R.H.'da stabilite deneylerine tabi tutulmuş Askorbik Asid tabletlerinin yüzde etken madde kaybı ve yüzde ortalama etken madde kaybı Tablo- V'de görülmektedir.

Tablo-V'deki değerler incelenerek stabilite testlerinde etken maddenin en çok kayba uğradığı dört formül ile etken maddenin en az kayba uğradığı dört formül, zamana karşı \% etken madde kaybı grafiğinde gösterilirse (Grafik-II). 
Tablo V. $\left(24^{\circ} \mathrm{G} \% 51\right.$ R.H. $)$

\begin{tabular}{|c|c|c|c|c|}
\hline Formül & $\begin{array}{c}\text { Başlangıç } \\
\% \text { Aktivite }\end{array}$ & $\begin{array}{c}\text { 1. Ay } \% \\
\text { Kayıp }\end{array}$ & $\begin{array}{c}\text { 2. Ay } \% \\
\text { Kayıp }\end{array}$ & $\begin{array}{c}\text { 3. Ay \% } \\
\text { Kayip }\end{array}$ \\
\hline 1 & 100 & 2,7 & 4,6 & 5,2 \\
2 & 100 & 0,6 & 2,5 & 2,5 \\
3 & 99,6 & 0,2 & 2,1 & 2,1 \\
4 & 99,35 & 0,35 & 5 & 5,5 \\
5 & 102,5 & 1,9 & 7,8 & 4,8 \\
6 & 101 & 2,9 & 3,5 & 6,2 \\
7 & 102,5 & 2,4 & 6,2 & 7,2 \\
8 & 103 & 0 & 4,5 & 3,3 \\
9 & 108,5 & 2,9 & 3,3 & 8 \\
10 & 101 & 0,9 & 3 & 9,8 \\
11 & 100,5 & 5 & 7,4 & 4 \\
12 & 106 & 5,6 & 9,2 & 5,2 \\
13 & 100,4 & 2,7 & 4 & 5,3 \\
14 & 101 & 3,2 & 4,1 & \\
\hline Ortalama $\%$ Kayıp & 1,8 & 4,8 & \\
\hline
\end{tabular}

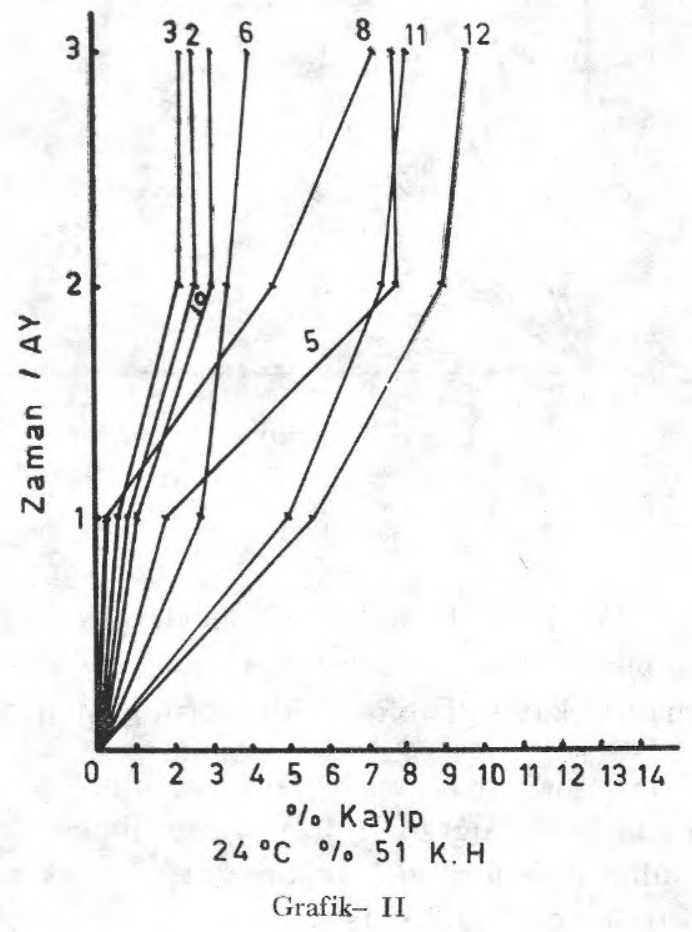


Burada ondört ayrı formülde etken madde kaybı (stabilite) yönünden $12,11,5,8$ nolu formüller en büyük değer kaybına uğramıştır. Buna mukabil 3, 2, 10, 6 nolu formüller en az değer kaybına uğramışlardır.

$20^{\circ} \mathrm{C}, \% 75$ R.H.'da stabilite testlerine tabi tutulmuş Askorbik Asid tabletlerinin yüzde etken madde kaybı ve yüzde ortalama etken madde kaybı Tablo-VI'da görülmektedir.

Tablo VI. $\left(20^{\circ} \mathrm{C} \% 75\right.$ R.H. $)$

\begin{tabular}{|c|c|c|c|c|}
\hline Formül & $\begin{array}{c}\text { Başlangıç } \\
\text { \% Aktivite }\end{array}$ & $\begin{array}{l}\text { 1. Ay } \% \\
\text { Kayıp }\end{array}$ & $\begin{array}{c}\text { 2. Ay \% } \\
\text { Kayıp }\end{array}$ & $\begin{array}{c}\text { 3. Ay \% } \\
\text { Kayıp }\end{array}$ \\
\hline 1 & 100 & 5,2 & 6,9 & 7,4 \\
2 & 100 & 2,2 & 5,8 & 5,8 \\
3 & 99,6 & 1,4 & 4,8 & 5,3 \\
4 & 99,3 & 1,9 & 5,6 & 8,4 \\
5 & 102,5 & 2,6 & 6,2 & 8,4 \\
6 & 101 & 2,6 & 5,2 & 5,7 \\
7 & 102,5 & 3,7 & 5,1 & 5,6 \\
8 & 103 & 2,9 & 4,9 & 5,6 \\
9 & 108,5 & 4,1 & 6,3 & 6,8 \\
10 & 101 & 3,5 & 4,6 & 9,3 \\
11 & 100,5 & 6,3 & 7,3 & 8,7 \\
12 & 106 & 3,3 & 6 & 4,1 \\
13 & 100,4 & 0,9 & 1,4 & 2 \\
14 & 101 & 0,5 & 0,5 & 6,4 \\
\hline Ortalama $\%$ Kayip & 2,9 & 5 & \\
\hline
\end{tabular}

Tablo-VI'daki değerler incelenerek stabilite testlerinde etken maddenin en çok kayba uğradığı dört formül ile etken maddenin en az kayba uğradığı dört formül, zamana karşı \% etken madde kaybı grafiğinde gösterilirse (Grafik- III).

Burada ondört ayrı formülde etken madde kaybı (stabilite) yönünden 11, 12, 5, 4 nolu formüller en büyük değer kaybına uğramıştır. Buna mukabil 14, 133 nolu formüller en az değer kaybına uğramışlardır.

\section{FIZIK BULGULAR}

Tabletler ilk imâl edildiği anda ve üç ay süreli stabilite testlerinin her periodunda fizik kontrollere tabi tutuldu. Bu kontrollerde, tabletlerin renklenme oranı gözle kontrol edilerek tesbit edildi, herhangi bir cihaz kullanılmadi. 


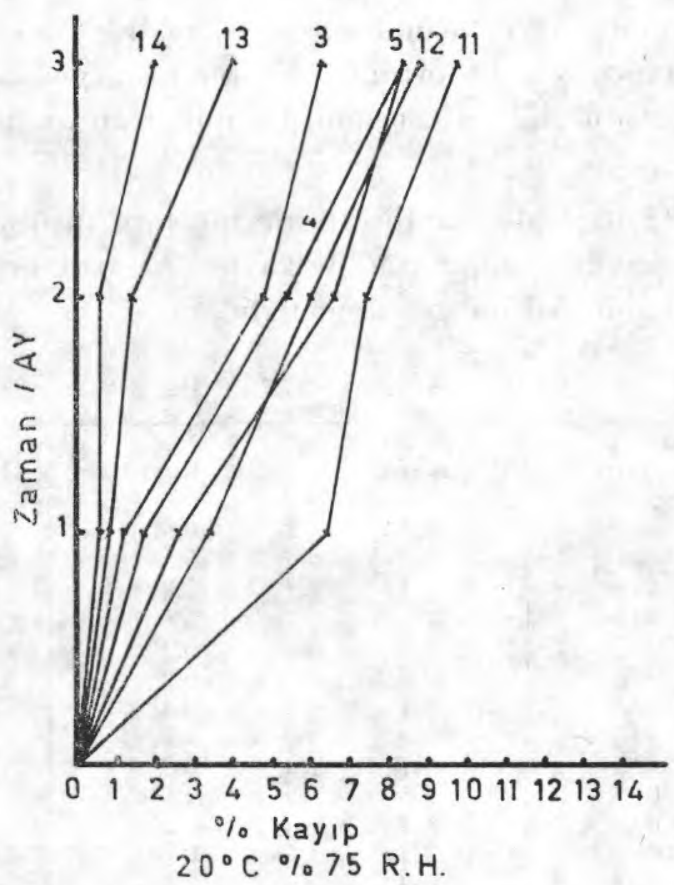

Grafik III

Tabletlerin renklenme oranı $(+,++,++4,++++)$ olarak gösterildi, bu işaretlerin her biri bir birim olarak alınarak, üç ay süre içerisinde, üç ayrı bağıl nemde teste tabi tabletlerin, renklenme oranı Grafik-IV'de tesbit edildi.

Grafik-IV'de görüldüğü gibi üç ayrı bağıl nemde teste tabi tabletlerde oluşan renk koyuluğu 1 ve 3 nolu eğrilerde büyük bir değer artışı göstermektedir.

$\mathrm{Bu}$ üç grupta sıcaklık bakımından farklı olmakla beraber iki grup \% 75 R.H. gibi yüksek bir bağıl nemde tutulmuşlardır. 2 nolu eğrinin daha az bir renk değişimi göstermesi, bu testlerde bağıl nemin tabletlerin renklenmesinde ne denli etkili olduğunu göstermektedir.

Grafik-IV'te eğrilerin maksimum yükselme gösterdiği noktalar en çok renklenen tablet formülleridir.

Ençok renklenme gösteren formüller ise, stabilite testlerinde en çok etken madde (stabilite) kaybına uğrayan formüllerdir. Renk- 
lenme ile kimyasal stabilite arasındaki ilişki literatürde belirtildiği gibi açıkca ortaya çıkmaktadır. (1)

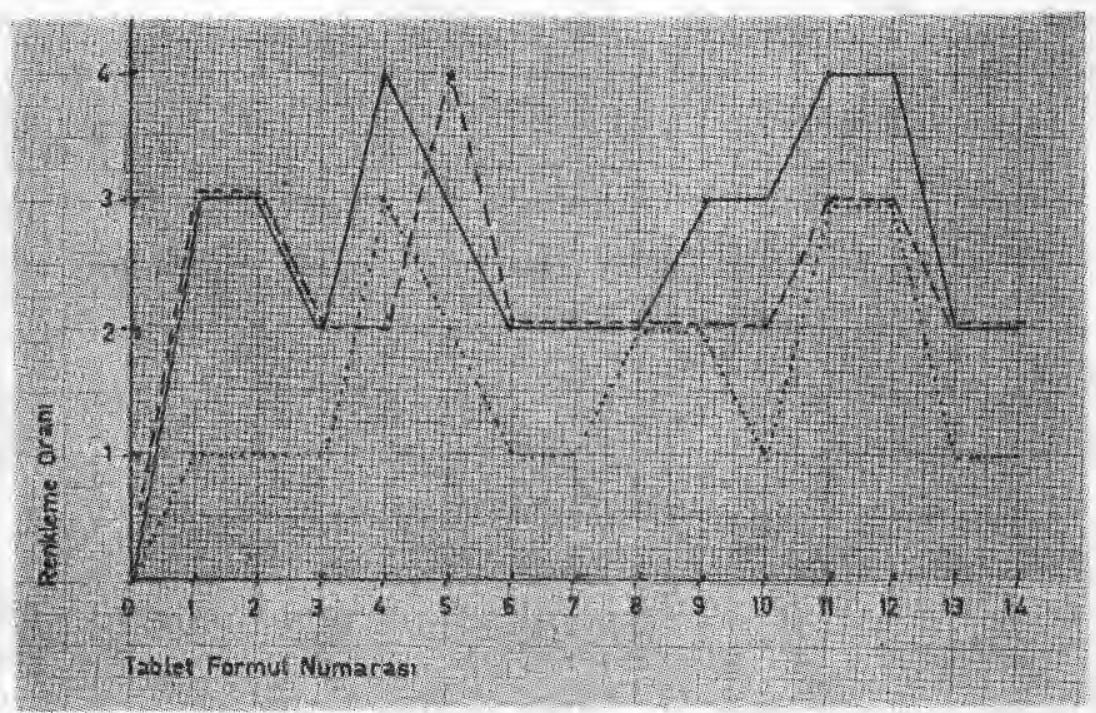

Grafik IV.

1. — $40^{\circ} \mathrm{C} \% 75$ R.H. stabilite testine tabi tabletler

2. $-24^{\circ} \mathrm{C} \% 51$ R.H. " $\quad$ " " " " " "

3. - $20^{\circ} \mathrm{C} \% 75$ R.H. " " "

Tablo VII. Tablet Askorbik Asid-Dağılma Zamanı, Dakika

\begin{tabular}{|c|c|c|c|c|}
\hline $\begin{array}{l}\text { Formül } \\
\text { No. }\end{array}$ & $\begin{array}{l}\text { Tablet Ilk Imâl } \\
\text { Edilince Dağilma } \\
\text { Zamanı /Dakika }\end{array}$ & $\begin{array}{c}40^{\circ} \mathrm{C} \% 75 \text { R.H. } \\
3 \text { Ay Sonra } \\
\text { Dakika }\end{array}$ & $\begin{array}{c}24^{\circ} \mathrm{C} \% 51 \text { R.H. } \\
3 \text { Ay Sonra } \\
\text { Dakika }\end{array}$ & $\begin{array}{c}20^{\circ} \mathrm{C} \% 75 \text { R.H. } \\
3 \text { Ay Sonra } \\
\text { Dakika }\end{array}$ \\
\hline $\begin{array}{r}1 \\
2 \\
3 \\
4 \\
5 \\
6 \\
7 \\
8 \\
9 \\
10 \\
11 \\
12 \\
13 \\
14\end{array}$ & $\begin{array}{r}10 \\
5 \\
6 \\
12 \\
6 \\
1 \\
1 \\
7 \\
10 \\
3 \\
9 \\
6 \\
1 \\
1\end{array}$ & $\begin{array}{r}4 \\
8 \\
2 \\
16 \\
17 \\
1 \\
2 \\
6 \\
15 \\
5 \\
22 \\
15 \\
1 \\
10\end{array}$ & $\begin{array}{r}2 \\
4 \\
2 \\
10 \\
2 \\
1 \\
1 \\
4 \\
9 \\
4 \\
9 \\
5 \\
1 \\
1\end{array}$ & $\begin{array}{c}4 \\
4 \\
2 \\
20 \\
3 \\
1 \\
1 \\
4 \\
14 \\
2 \\
21 \\
8 \\
1 \\
3\end{array}$ \\
\hline $\begin{array}{l}\text { Ortalam } \\
\text { Zamani }\end{array}$ & $\begin{array}{l}\text { Dağılma } \\
\text { Dakika } 5,5\end{array}$ & 8,8 & 3,9 & 6,2 \\
\hline
\end{tabular}




\section{DAĞILMA KONTROLU}

Tabletler ilk imâl edildiği anda ve üç ay süreli stabilite deneylerinin her periodunda $0,1 \mathrm{~N}$ HCI içinde yapıldı. Tablo-VII'de görüldüğü gibi $40^{\circ} \mathrm{G} \% 75$ R.H.'da ve $20^{\circ} \mathrm{C} \% 75$ R.H.'da 3 ay süre ile stabilite testlerine tabi olan tabletlerin dağılma zamanları, tabletlerin ilk dağılma zamanlarına göre uzamış ve $24^{\circ} \mathrm{C} \% \quad 51 \quad$ R.H.'da teste tabi tabletlerin dağılma zamanı kısalmıştır.

Bağıl rutubetin genellikle tabletlerin dağılma zamanını etkilediği ve bu süreyi uzattığı görülmektedir.

\section{SERTLIK KONTROLU:}

Stabilite testlerine tabi tutulan tabletlerden her grubundan en az altı tablette sertlik tayini yapıldı ve ortalamaları alındı.

Tablo-VIII'de görüldüğü gibi $40^{\circ} \mathrm{G} \% \quad 75$ R.H.'da stabilite testlerine tabi tutulan tabletler üç ay sonunda ilk imâl edildiklerindeki sertliklerinden $\% 42$ kaybetmişler, $24^{\circ} \mathrm{C} \% 51$ R.H.'da stabilite testlerine tabi tabletler sertliklerinden $\% 29$ kaybetmişlerdir. ve $20^{\circ} \mathrm{C}$ \% 75 R.H.'da tabletler sertliklerinden \% 49 kaybetmişlerdir.

Tablo VIII. Tabletlerde Sertlik Tayin Sonuçları

\begin{tabular}{|c|c|c|c|c|}
\hline $\begin{array}{l}\text { Formül } \\
\text { No. }\end{array}$ & $\begin{array}{l}\text { Tablet Ilk Imâl } \\
\text { Edildiğinde } \\
\text { Sertlik/Kg. }\end{array}$ & $\begin{array}{c}40^{\circ} \mathrm{C} \% 75 \text { R.H. } \\
3 \text { Ay Sonra } \\
\text { Sert } / \mathrm{Kg} .\end{array}$ & $\begin{array}{c}24^{\circ} \mathrm{C} \% 51 \mathrm{R} . \mathrm{H} . \\
3 \text { Ay Sonra } \\
\text { Sert } / \mathrm{Kg} .\end{array}$ & $\begin{array}{c}20^{\circ} \mathrm{C} \% 75 \text { R.H. } \\
3 \text { Ay Sonra } \\
\text { Shert } / \mathrm{Kg} .\end{array}$ \\
\hline $\begin{array}{r}1 \\
2 \\
3 \\
4 \\
5 \\
6 \\
7 \\
8 \\
9 \\
10 \\
11 \\
12 \\
13 \\
14\end{array}$ & $\begin{array}{l}2,8 \\
5,6 \\
4,4 \\
6,4 \\
6,7 \\
4,3 \\
4,7 \\
4,6 \\
8,4 \\
4,5 \\
6 \\
7,4 \\
6,6 \\
5\end{array}$ & $\begin{array}{l}2,6 \\
3,2 \\
3,3 \\
3,8 \\
3,1 \\
1,8 \\
0,2 \\
3,8 \\
4,6 \\
3,9 \\
4 \\
4,9 \\
2,8 \\
2,5\end{array}$ & $\begin{array}{l}2,6 \\
5,6 \\
3,9 \\
5,6 \\
4,5 \\
2,6 \\
3 \\
4,3 \\
7,2 \\
3,5 \\
5,3 \\
5,1 \\
0,8 \\
1,4\end{array}$ & $\begin{array}{l}2,6 \\
2,8 \\
3,1 \\
3,8 \\
3,2 \\
2,0 \\
1,7 \\
3,2 \\
4,3 \\
3,7 \\
2,4 \\
3,8 \\
1,1 \\
1,3\end{array}$ \\
\hline \multicolumn{2}{|c|}{ Ortalama Sertlik Kaybı \% } & 42 & 29 & 49 \\
\hline \multicolumn{2}{|c|}{$\begin{array}{l}\text { Ortalama } \\
\text { Sertlik/Kg. }\end{array}$} & 3,1 & 3,9 & 2,7 \\
\hline
\end{tabular}


Bağıl nemin tabletlerin sertliklerinde oldukça etkili olduğu görülmüştür.

Kimyasal stabilite yönünden en dayanıksız olan $5,4,11,12$ nolu formüller ile kuru yöntemle hazırlanan $6,7,13,14$ nolu formüller sertlik bakımından da büyük kayıp gösteren formüllerdir. Sertliklerinden en az kayba uğrayan 1, 3, 8, 10 nolu formüller, kimyasal stabilite yönünden de oldukça stabil formüllerdir.

Askorbik Asid tabletlerinin kimyasal stabilitesi ve tabletlerin imâl yöntemleri ile tablet sertlik dereceleri arasında bir ilişki olduğu düşünülebilir.

\section{SONUÇ VE TARTIŞMA}

Askorbik Asid'in stabilitesi üzerine; yapıştırıcı, kaydırıcı ve dağıtıcı olarak kullanılan nişasta türlerinin etkisi ondört ayrı formülün değişik sıcaklık ve rutubetlerdeki durumları ile incelenmiştir. Deneylerin sonunda (Tablo-IV, V, VI) Kristal Askorbik Asid ile yapılmıs olan tabletler ile kaplanmıs Askorbik Asid ile yapılan tabletlerin ortalama yüzde etken madde kayıpları hesaplandığında (Tablo-IX), Kristal Askorbik Asidle yapilan tabletlerin genellikle kaplanmış (Etilsellüloz) Askorbik Asid ile yapılan tabletlere nazaran farklı olmadıkları görüldü. Dolayısiyle kaplanmış Askorbik Asid'in deney şartlarımızda stabilite yönünden koruyucu bir etkisinin olmadığı kanısına varıldı. Bu sonuçlarımız literatüre de (1) uymaktadır.

Tablo IX.

\begin{tabular}{|c|c|c|c|c|c|c|c|c|c|}
\hline & \multicolumn{3}{|c|}{$\begin{array}{c}40^{\circ} \mathrm{C} \% 75 \text { R.H. } \\
\text { Ortalama \% } \\
\text { Stabilite Kaybı }\end{array}$} & \multicolumn{3}{|c|}{$\begin{array}{l}24^{\circ} \mathrm{C} \% 51 \text { R.H. } \\
\text { Ortalama \% } \\
\text { Stabilite Kaybı }\end{array}$} & \multicolumn{3}{|c|}{$\begin{array}{c}20^{\circ} \mathrm{G} \% 75 \text { R.H. } \\
\text { Ortalama \% } \\
\text { Stabilite Kaybı }\end{array}$} \\
\hline & 1. Ay & 2. Ay & $3 . \mathrm{Ay}$ & 1. Ay & 2. Ay & 3. Ay & 1. Ay & 2. Ay & 3. Ay \\
\hline $\begin{array}{l}\text { Askorbik Asid } \\
\text { Kristal Toz }\end{array}$ & 3,8 & 6,3 & 7,8 & 1,5 & 3,6 & 3,8 & 2,8 & 5,6 & 6,6 \\
\hline $\begin{array}{l}\text { Kaplanmıs } \\
\text { Askorbik Äsid }\end{array}$ & 4,0 & 6,2 & 8,2 & 1,6 & 4,2 & 4,9 & 3,1 & 5,1 & 6,9 \\
\hline
\end{tabular}

Çabuklaş̧ırılmış stabilite testlerinde $40^{\circ} \mathrm{C} \% 75$ R.H.'da $24^{\circ} \mathrm{C}$ $\% 51$ R.H.'de ve $20^{\circ} \mathrm{C} \% 75$ R.H.'da Askorbik Asid tabletlerinin etken madde kaybı ortalaması zamanla artmakta (Tablo-IV, V, VI) olduğu görülmüştür. 
$\mathrm{Bu}$ üç grup teker teker incelendiğinde $40^{\circ} \mathrm{C} \% 75$ R.H.'da słabilite testine tabi tutulan ondört ayrı tablet formülünden sira ile 11, 4, 12, 5 nolu formüller en büyük etken madde kaybına uğramışlardır. Buna mukabil 14, 3, 8, 13 nolu formüller en küçük etken madde kaybına uğramıslardır, yani en stabil formüllerdir. (Grafik-1) 11, 4, 12, 5 nolu Askorbik Asid tabletlerinde Ev Tipi Nişasta kullanılmıştır. Buna mukabil 14, 3, 8, 13 nolu Askorbik Asid formüllerinde endüstri tipi nişasta kullanılmıştır.

$24^{\circ} \mathrm{C} \% 51$ R.H. da stabilite testine tabi tutulan Askorbik Asid tabletlerinden $12,11,5,8$ nolu formüller en yüksek etken madde kaybına uğrayan formüllerdir. 8 nolu formül hariç diğerleri ev tipi nişasta ile yapılmış tabletlerdir. Buna mukabil 3, 2, 10, 6 nolu formüller en az etken madde kaybina uğramışlar (Grafik-2) dır. Bu formüller endüstri tipi nişasta ile yapılmışlardır. $20^{\circ} \mathrm{C} \% 75$ R.H.'da stabilite testine tabi tutulan Askorbik Asid tabletlerinden sira ile 11, 12, 5, 4 nolu formüller en yüksek etken madde kaybına uğramışlar buna mukabil bu grupta en az kayı 14, 13 ve 3 nolu formüllerde görülmüştür. (Grafik-3) En çok etken madde kaybına uğrayan 11, $12,5,4$ nolu formüller ev tipi nişasta ile yapilmış tabletlerdir. En az kayba uğrayan 14, 13, ve 3 nolu formüller endüstri tipi nişasta ve Mikrokristalin Sellülozla yapılmış tabletlerdir. Ưç ayrı sıcaklık ve bağıl nemde stabiliteleri incelenen ondört Askorbik Asid tablet formülü içinde en stabil formüllerin endüstriel nişasta ile yapılan tabletler olduğu, en lâbil formüllerin ev tipi nişasta ile yapılan tabletler olduğu kanısina varılmıstır.

Stabilite testlerinde kullanılan Nişastalar madensel maddeler yönünden incelendiğinde Tablo- $\mathrm{X}$ görülür ki ev tipi nişastalar endüstriel nişastalara nazaran çok daha fazla madensel maddeler ihtiva etmektedir. Madensel maddelerden bakır, endüstriel nişastalarda, kullandığımız metod (17) ile tesbit edilememiştir. Ev tipi nişastalarda ise $\% 0,4 \mathrm{mg}$. bakırın mevcudiyeti tesbit edilmiştir.

Tablo X. Çeşitli nișastalarda kül miktarı*

\begin{tabular}{|l|c|c|c|}
\hline Cinsi & $\begin{array}{c}\text { Hububat unlarında } \\
\% \text { kül miktarı }\end{array}$ & $\begin{array}{c}\text { Endüstr. Nişastalar } \\
\% \text { kül miktarı }\end{array}$ & $\begin{array}{c}\text { Ev tipi Nişastalarda } \\
\% \text { kül miktarı }\end{array}$ \\
\hline Mısır & $1,5 \mathrm{~g}$. & $0,05 \mathrm{~g}$. & $1,5 \mathrm{~g}$. \\
Buğday & $0,4 \mathrm{~g}$. & $0,03 \mathrm{~g}$. & $0,86 \mathrm{~g}$. \\
Patates & $0,1 \mathrm{~g}$. & $0,13 \mathrm{~g}$. & $0,38 \mathrm{~g}$. \\
\hline
\end{tabular}

* Miktarlar üç ayrı tayin ortalamasıdır. 
Protein miktarı yönünden Ev tipi nişastaların endüstride yapılanlara kıyasla çok miktarda Protein içerdikleri (Tablo-XI) saptanmışlardır.

Tablo XI. Nişastalarda Protein* Miktarları

\begin{tabular}{|c|c|}
\hline Nişastalar & Protein \% \\
\hline Buğday Nişastası (Endüstri) & 0,526 \\
\hline Misir & 0,351 \\
\hline Patates & 0,052 \\
\hline (Ev Tipi) & 1,732 \\
\hline Misir & 4,25 \\
\hline Patates " " & 0,122 \\
\hline Buğday (Hububat unu) & $8-13$ \\
\hline Misir " " & $8-10$ \\
\hline Patates " & 2 \\
\hline
\end{tabular}

(*) miktarlar üç ayrı tayinin ortalamasıdır.

Askorbik Asid tabletlerinde seyreltici ve bağlayıcı olarak kullanılan nişastaların içerdiği protein miktarı ile tabletlerin kimyasal stabiliteleri arasında bir münasebet kurmak mümkündür.

Deneyler göstermiştir ki, Askorbik Asid tabletlerinde kullanılan nişastalar neoranda protein içerirse, tabletlerde etken madde o nisbette kayba uğramaktadır. O halde Askorbik Asid tabletlerinin yap1minda kullanılacak nişastanın çok iyi seçilmesi gerekmektedir.

Çalı̧̧malarımızda, Grafik 1, 2, 3 de görüldüğü gibi 3 nolu Askorbik Asid formülü kimyasal stabilite yönünden diğer formüllere nazaran en stabil formüldür. Bu formülde kullanılan nişasta endüstri tipi patates nişastasıdır ve tablo-XI'de görüldüğü gibi diğer nişastalara göre daha az protein ihtiva etmektedir. Nişastadaki proteinlerin Askorbik Asid tabletlerinde etken maddeye olumsuz etkisinin, bazı özelliklerinden ileri geldiği kanısındayız. Şöyleki; proteinlerin pozitif ve negatif grupları hidratasyona uğrayabilir. Meselâ $100 \mathrm{~g}$. proteine genellikle $50 \mathrm{~g}$. hidrat suyu bağlanabilir, bu su proteine çok kuvvetle bağlanır ve başka maddeleri çözme yeteneği yoktur.

Peptit bağlarıda hidrat suyu bağlar, peptit lifleri arasında bağlanan molekül suyu normal çözme yeteneğini gösterir. (8)

$\mathrm{Bu}$ işlemle bünyesine suyu bağlayabilen Nişasta içerisindeki protein, Askorbik Asid'in aşağıdaki sebeplerle parçalanmasını hızlandirabilir. 
a) Su ile devamlı temasını sağlayarak hava oksijeninin etkisi ile kolaylıkla dehidratasyon ve hidratasyon olayını hızlandırmaktadir.

b) Proteinlerin tuttukları su, ev nişastalarındaki eser miktarda bakırın katalitik etkisini kolayca ve daha hızh göstermesine ortam hazırlamaktadir.

c) Proteinlerin Amfolit karakterleri Askorbik Asid karşısında ve yaş ortamda karşıt yük kazanarak Askorbik Asid'in çabucak oksitlenmesine sebep olmaktadir.

Askorbik Asid tabletlerinin şüphesiz yaş yöntem veya kuru yöntemle yapılması arasında, stabilite yönünden farklar mevcuttur. Bu konuda literatür Askorbik Asid tabletlerinin stabil kalabilmesi için kuru yöntemle tablet yapılmasını önermektedir. (4) Ancak kuru yöntemde de nişasta dağıtıcı ve kaydırıcı olarak kullanılabilmektedir.

Stabilite deneylerimizde bu konuyu dikkate alarak dört ayrı formül (Mikrokristalin Sellüloz) ve çözünebilen Misır Nişastası STR$\mathrm{x}-1500$ (14) kullanarak kuru yöntemle hazırlanmıstır. Bu tabletler $(6,7,13,14$ nolu formüller) stabilite testlerinde, yaş yöntemle hazırlanan formüllere nazaran daha iyi neticeler vermişlerdir. Literatürde STR $-\mathrm{x}-1500$ ile yapılan tabletlerde, stabilite yönünden STR-x1500 'ün büyük bir etkisinin olmadığından bahsedilir. (1) Bu neticeyi bizde çalışmalarımızda kanıtlamıs bulunmaktayız.

Askorbik Asid tabletleri ister kuru, ister yaş yöntemle hazırlansin stabilite yönünden temperatür ve bağıl nem etkili bir faktör olarak görülmektedir.

Burada ortalama $\%$ etken madde kaybı en büyük değeri $40^{\circ} \mathrm{C}$ $\% 75$ R.H.'da en az kaybı ise $24^{\circ} \mathrm{C} \% 51$ R.H.'da ve ortalama değeri $20^{\circ} \mathrm{C} \% 75$ R.H.'da göstermektedir. Buradan da Askorbik Asid tabletlerinde stabilitenin sıcaklık ve bağıl nem ile sıkı sıkıya ilişkili olduğu görülmektedir. Ayrıca zaman faktörünün etkisi ile ortalama etken madde kaybının artmakta olduğu grafik-5'te bariz olarak görülmektedir. Askorbik Asid tabletlerinin normal sicaklik normal nemde muhafaza edildiğinde dahi rengini değiştirdiği bilinmektedir.

Yaptığımız deneyler göstermiştir ki, Askorbik Asid tabletlerinin renklenmesinde (kimyasal stabilitesinde) sadece sicaklık ve nem olanakları etkili değildir, fakat tablet formüllerine konan dolgu 
maddeleri, kaydırıcılar ve bağlayıcılarında etkisi yüksektir. $(20,21)$ Grafik-4'te değişik sicaklık ve bağıl nemde Askorbik Asid tabletlerinin renklenme şiddeti eğrileri görülmektedir. Ordinat üzerindeki iki taksimatın üstündeki değerler en çok renklenen tablet formülleri veya bir başka ifade ile kimyasal stabilite bakımından en zayıf tabletler olup, bunlarda 4, 5, 11, 12 nolu formüllerdir. Bu formüller Ev Nişastası ile hazırlanmış formüllerdir. Keza ordinat üzerindeki iki taksimatın hizasında ve bunun altındaki formüller en az renklelenen tablet formülleri veya en stabil formüllerdir ve endüstriel nişastalarla hazırlanmıslardır. Tabletlerin renklenme şiddetini karşılaştırarak yapılan tayinlerde değişik bağlayıcı ve seyrelticilerin renk stabilitesi ve dolayısile kimyasal stabilite üzerindeki etkisi açıkça görülen en önemli belirtidir.

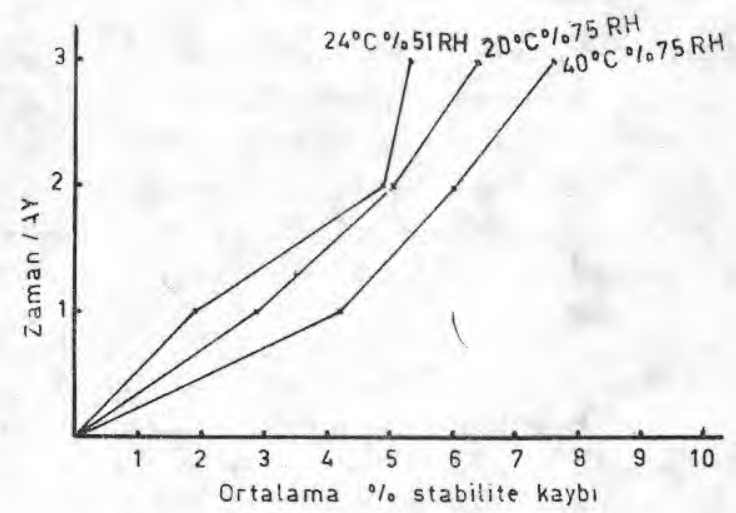

Grafik 5

Stabilite deneylerinin sonuçları göstermiştir ki; tabletlerde bağlayıcı ve seyreltici olarak kullanılan çeşitli nişastalar içerdikleri protein oranında Askorbik Asid'in stabilitesine etkili olmaktadır. Bu etkide Ev Nişastalarının içerdikleri bakırın rolüde olduğu muhakkaktır. Etken maddenin parçalanması yanında dağılma zamanı ve tablet sertliği bakımından da nişasta türlerinin etkili olduğu anlaşılmıştır. Incelemelerimizde görülmüştürki, ülkemizin bir yıllık bağıl nem ortalaması da göz önüne alınarak tertip edilen stabilite çalışmalarında Askorbik Asid tabletleri en az \% 2 ve en fazla \% 14 gibi bir etken madde kaybına uğramaktadır. Bu etki kaybını da; Askor- 
bik Asid tabletinin yapımında kullanılan nişastanın cinsinin, nişastanın protein içeriğinin ve ayrıca bakır ve diğer ağır metallerin mevcudiyetinin önemli etkisi olduğu sonucuna varılmıştır.

\section{ÖZET}

Ưlkemizde elde edilen çeşitli nişasta tipleri (Ev ve Endüstriel) yardımcı madde olarak kullanılmak suretiyle Askorbik Asid'in dayanıkhlığı üzerindeki etkileri incelendi: Bu amaçla ondört ayrı Askorbik Asid tablet formülü üzerinde çalı̧ılld. Tabletlerde ev tipi ve Endüstriel tipte, Buğday, Mısır, Patates nişastaları çözünebilen Mısır Nişastası (STR-x-1500), Mikrokristalin Sellüloz kullanıldı.

Formüllerden yedisi kristal toz Askorbik Asid ile yedisi de kaplanmış Askorbik Asid ile hazırlandı. Formüllerden on tanesi yaş yöntem ile dört tanesi de kuru yöntemle hazırlandı.

Stabilite deneyleri dört farklı bağıl nem ortamında, üç farklı temperatürde, üç ay süre ile yürütüldü. Bu yöntemle bağıl nem sıcaklık ve zaman faktörlerinin etkisi ile meydana gelen değişiklikler çeşitli yöntemlerle tayin edildi. Tabletler önce hiç bir şarta tabi tutulmadan, sonra deney şartlarında testler yapıldı. Her ay sonunda tabletlerde miktar tayinleri, dağılma testleri, sertlik tayinleri, renk farkları tesbit edildi.

Ev (Küçük Sanayi) ürünü nişastalarla hazırlanan Askorbik Asid tabletlerinin çabuk bozulduğu saptandı, nedenler araştırıldı, Ev nişastalarında endüstri ürünlerine göre daha yüksek miktarda Protein ve Bakır bulunduğu tesbit edildi.

Ev ve küçük sanayi tipi nişastalardaki proteinin su tutma yeteneği ve miktarı ile Bakırın katalizör etkisinin müştereken etken maddenin bozulmasını oluşturduğu kanısına varıldı.

Farmakopelerdeki nişasta kalitesi tayinlerinde protein ve bakır aranması gerekliliği sonucuna varıldı.

\section{SUMMARY}

The effects of starch's quality which are produced in Turkey by different process on the stability of ascarbic acid tablets have been investigated. Fourteen different tablet formulas have been prepared for this purpose. 
In these tablets, the types of starch, industrial and home made (small industry) types of wheat, Corn, potatoes and soluble corn starch (STR-x-1500) and microcrystalline cellulose have been used.

Seven formulas have been prepared by using crystal ascorbic acid and seven by using coated ascorbic acid; ten formulas by the wet method, four formulas by dry method.

The stability experiments were conducted in four different relative humudity mediums and at three different temperatures for three months.

Thus, changes due to relative humudity, temperature and time factor have been determined by various methods. These tests were first carried out on the tablets just prepared and then again at the end of the experimantal period.

At the end of every month, the ascorbic acid, the disintegration time, hardness, and colour difference of the tablets were determined.

The more rapid decomposition ascorbic acid was observed in tablets which were prepared using the starches of the small industry production.

To find the reason of the rapid decomposition of ascorbic acid in tablets we prepared. We worked on the quality of starches which were purchased from the marked. It was found that the protein and copper contents of the staches which were produced by the small industry were more higher then those of the big industrial product.

We hawe concluded that, the decomposition of the active subtance was due to both the water absorption capacity of the protein and the catalytic effect of copper within the starches of the small industry production. It may be concluded that to add the determinations of the protein and copper content into the quality control methods of starches would be of help in the stability of some drugs in tablets. 


\section{LITERATÜR}

1. Robert B. Wortz., 7. Pharm. Sci. Vol 56, No. 9. 1169-1173 (1967)

2. Krishna S. Manudhane, Avisnash M. Gontractor, Hyo Y.Kim and Ralph F. Shangraw., Ibid F. Pharm. Sci, Vol. 58., No. 5., 616 (1969).

3. Manzur-Ui-Haque Hashmi., Assay of Vitamins in Pharmaceutical Preparation., John Wiley and Sins London., 286-321 (1973.

4. Seth. S.K. And Mital, H.C., Indian F. Pharm. 27, 11y, 121 (1y65).

5. A. Szent Gyorgyi., Biochem., 221387 (1928)

6. W.H. Sebrell., J.R., Robert S. Harris. The Vitamins, Volum-1, 306-329 (1967).

7. Aras Kâzım., Rota Gemil., Bingöl Gazanfer., Tıbbî Biokimya ve Vitaminler 103-111 (1954).

8. Haurowitz Felix., Biokimya., 4. Bask1., 127. 156. 189. 190 (1948).

9. Türk Farmakouesi., 1974 S. 13, 828.

10. Wallis T.E., Taxboot of Pharmacocnosy., 7-10 J.A. Churchill, Ltd. 104 Gloucester Place, London, W.1. (1967).

11. Kirk Otmer., Encyclopedia of Chemical Technology., Second Edition, Volum 19, Jonh Wiley and Sons Inc. (1962)

12. Tanker Mekin - Tanker Nevin., Farmakognozi, Cilt 1, 263-271. Öz Işık Matbaası, İstanbul (1973).

13. İzgü Enver., Genel ve Endüstriel Farmasi., Gilt 2, 180-184 (1973).

14. Staley. TDS. No. MC 503, 864040, Technical Data Sheet. A.E. Staley Mfg. Co. Decatur, 111, U.S.A. (1969)

15. Pharmacopeia of The United States of America (XVIII)., 18 th Rev. Mack Printing Co., Easton, 52-43 (1970).

16. J.W. Knight., The Starch Industry., Pergamon Pres Ltd., London-W-I., 32-181 copy righ (1969).

17. Andrew, L. Winton and Kate Barber, Winton., The Analysis of Foods., London. 261, Copyright (1945).

12 Milton A. Bridges and Marjorie., R. Wattice., Food and Beverage Analysis 228231 (1942).

19. Physical and Chemical Hand Book 51., St. E. 40. (1970-1971).

20. Blaugh M.R., Chakravarty., D. and Lagh., J.L. Drugs Std. 27. 199 (1958).

21. Wai., K. Dekay, H.G. And Barker., G. S. J. Pharm. Sci., 51, 1076 (1962). 